\title{
Is intracouple assisted reproductive technology an option for men with large-headed spermatozoa? A literature review and a decision guide proposal
}

\author{
Bruno Guthauser $^{1 *}$, Xavier Pollet-Villard ${ }^{2}$, Florence Boitrelle 3,4 and Francois Vialard ${ }^{3 *}$
}

\begin{abstract}
Although the presence of spermatozoa with an abnormally large head is rare, it is associated with low fertility or even total infertility. We reviewed the literature on assisted reproductive technology (ART) strategies and outcomes for men with large-headed spermatozoa. We also discuss additional analyses that can usefully characterize sperm defects and help with the choice between intra-couple ART and insemination with donor sperm. Lastly, we propose a classification for cases of large-headed spermatozoa.
\end{abstract}

Keywords: Macrocephalic sperm head syndrome, Large-headed spermatozoa, Assisted reproductive technology outcomes, Fluorescence in situ hybridization, Sperm head measurement

\section{Résumé}

La présence de spermatozoïdes macrocéphales est généralement associée à une hypofertilité ou une infertilité. Nous présentons une revue de la littérature concernant les stratégies de prise en charge en aide médicale à la procréation et leurs issues lorsque l'analyse du sperme met en évidence la présence de spermatozoïdes macrocéphales. Nous discutons également les examens complémentaires permettant de mieux caractériser ces anomalies spermatiques et de choisir entre l'aide médicale à la procréation avec ou sans donneur de sperme. Enfin nous proposons ici une classification pour les cas de spermatozoides macrocephales avec pour les 6 types définis une proposition de prise en charge.

Motsclefs: Syndrome des spermatozoïdes macrocéphales, Spermatozoïdes macrocéphales, Issue des aides médicales à la procréation

\section{Background}

Large-headed spermatozoa are defined as those with a length $>4.7 \mu \mathrm{m}$ and a width $>3.2 \mu \mathrm{m}$ [1]. A number of different terms have been used to refer to these spermatozoa, including "macrocephalic sperm" [2-5], "megalohead" spermatozoa [6] "enlarged-head spermatozoa" or "enlarged forms" [7-9], "macronuclear spermatozoa" [10] and "large head spermatozoa" [11]. Men with large-headed

\footnotetext{
* Correspondence: brunoguthauser@gmail.com; francois.vialard@uvsq.fr ${ }^{1}$ Laboratoire de Biologie de la Reproduction, Hôpital Tenon, Paris, France ${ }^{3} \mathrm{GIG}$, EA7404, Université Versailles St Quentin en Yvelines, Montigny le Bretonneux, France

Full list of author information is available at the end of the article
}

spermatozoa (who may have a normal sperm count per se) account for less than $1 \%$ of cases of severe male infertility. The condition is associated with poor fertility or even complete infertility. Accordingly, in the past 20 years, very few babies have been fathered by men with large-headed spermatozoa as part of assisted reproductive technology (ART) programmes - raising the question of whether donor sperm should be used in this context. Here, we review the scientific literature on ART programmes and outcomes for men with large-headed spermatozoa. We also discuss the potential value of additional analyses in the decision-making process for men with large-headed 
spermatozoa. Lastly, given that the case reports range from the classic scenario (macrocephalic sperm head syndrome, MSHS, in which nearly all spermatozoa have large heads and multiple flagella) to those featuring less severe sperm abnormalities, we propose a new classification that we hope will enable physicians to help their patients to choose between intracouple ART and insemination with donor sperm.

\section{Methods}

We performed a systematic review of the relevant literature, in accordance with the PRISMA guidelines. In PubMed database we used the following terms: "macrocephalic sperm", "enlarged head spermatozoa", macronuclear spermatozoa", "sperm head measurements", large-head spermatozoa". Only studies with a fully described sperm morphology including photographies or precise sperm characteristics were considered.

\section{Literature review (Table 1)}

The first clinical report of spermatozoa with an abnormally large head and multiple flagella (MSHS) was published almost 40 years ago [12]. A further six cases were described over the following years [13]. Since then, a wide range of clinical contexts has been reported on. The percentage of large-headed spermatozoa in the semen varies; it can be very high (and even $100 \%$ ) in some patients and low to moderate in others (Table 1). These clinical variations differ from the original case report and are discussed below.

Cases with a high percentage of large-headed spermatozoa with an uneven shape and multiple flagella: MSHS

A high proportion of irregularly shaped, multi-tailed spermatozoa (see photograph 1 in Table 2) is associated with severe male infertility. High rates of polyploidy and aneuploidy have been described in these cases [2-4, 14-16]. Most studies have highlighted a highly abnormal sperm chromosomal content, which suggests a high genetic risk for the conceptus. Viville et al. reported a patient in whom $64 \%$ of the spermatozoa had a large head and multiple flagella; in a fluorescence in situ hybridization (FISH) analysis, $89.2 \%$ of the spermatozoa were found to be aneuploid or polyploid [2]. Benzaken et al. described a case in which all the spermatozoa were large-headed and polyploid; ICSI was therefore contraindicated [3]. Devillard et al. found for 3 patients with large headed sperm and multiflagella a polyploidy chromosomal constitution, and ICSI was not recommended nor performed [17]. In 2006 , we reported on two patients in whom respectively $91 \%$ and $82 \%$ of the spermatozoa were large-headed. Interestingly, $95 \%(27 / 28)$ and $90 \%(46 / 51)$ of the few spermatozoa with a normal-sized head had an abnormal chromosomal content (according to a FISH analysis of chromosomes $\mathrm{X}, \mathrm{Y}$ and 18). Insemination with donor sperm was therefore recommended [4]. Lastly, Perrin et al. studied the chromosomal status of large-headed spermatozoa with multiple flagella and decided not to recommend ART with the patient's sperm [16].

\section{Cases with a moderate percentage of large-headed spermatozoa}

Yurov et al. described a patient in whom $40 \%$ of spermatozoa had abnormally large heads. However, all the spermatozoa had a regular shape and normal flagella (see photograph 2 in Table 1) [11]. Similarly, Vicari et al. reported on three patients in whom respectively $54 \%$, $19 \%$, and $26 \%$ of the spermatozoa had an abnormally large head [18]. Achard et al. published a report on four cases, in whom respectively $19 \%, 22 \%, 29 \%$ and $49 \%$ of the spermatozoa had a large head. The sperm head's shape was irregular in three of the patients and regular in one. In line with the proportions of large-headed spermatozoa, a FISH analysis of three chromosomes revealed that respectively $25.6 \%, 43.6 \%, 51.4 \%$ and $71.7 \%$ of the spermatozoa were aneuploid or polyploid [10].

\section{Intra-couple ART and pregnancy outcomes}

Over the past 20 years, 18 publications have reported on a total of 124 patients with large-headed spermatozoa. Sperm chromosome analysis was performed in almost all of these studies; the FISH results and intracytoplasmic sperm injection (ICSI) outcomes are summarized in Table 1. One hundred and one patients (in 9 different studies) entered intracouple ICSI programmes, whereas ICSI was contraindicated for 23 patients in 8 studies. A total of 111 ICSI cycles were performed but $94 \%$ of these attempts failed - even when embryos were obtained (Table 1). Ben Khelifa et al. [9] reported the performance of 11 ICSI cycles with sperm from 2 patients. All the spermatozoa were large-headed and respectively $28 \%$ and $52 \%$ of the spermatozoa had multiple flagella. 26 embryos were transferred but none resulted in a pregnancy.

The 111 ICSI cycles resulted in 5 live births. Kahraman et al. reported on a series of 22 ICSI cycles. The fertilization rate $(43 \%)$ and the pregnancy rate $(9 \%)$ per cycle were low. Nineteen embryo transfers resulted in 2 pregnancies and 3 live births [6]. Achard et al. reported on 7 ICSI cycles in 4 patients with a moderate proportion of large-head spermatozoa. The sole reported pregnancy resulted in a live birth [10]. In 2012, Shimizu et al. reported the birth of a healthy baby after ICSI for a patient with MSHS. They wrote that "almost all spermatozoa had enlarged heads and multiple flagella", although the percentage was not specified and additional assessments (such as a FISH analysis) were not undertaken. ICSI was 
Table 1 Reports of patients with large-headed spermatozoa and the associated ART decisions and outcomes

\begin{tabular}{|c|c|c|c|c|c|c|c|c|c|c|}
\hline \multirow[t]{2}{*}{ Reference } & \multirow{2}{*}{$\begin{array}{l}\text { Number of } \\
\text { patients }\end{array}$} & \multicolumn{2}{|c|}{ Spermatozoa with } & \multicolumn{3}{|c|}{ Description of semen } & \multirow{2}{*}{$\begin{array}{l}\text { Spermatozoa with } \\
\text { aneuploidies }\end{array}$} & \multirow[t]{2}{*}{ Additive analysis } & \multirow{2}{*}{$\begin{array}{l}\text { Status of } \\
\text { intracouple ART }\end{array}$} & \multirow{2}{*}{$\begin{array}{l}\text { Outcome }(\mathrm{s}) \text { for ART programmes } \\
\text { with the patient's sperm }\end{array}$} \\
\hline & & Large heads & $\begin{array}{l}\text { Multiple } \\
\text { flagella }\end{array}$ & $\begin{array}{l}\text { Sperm count } \\
\left(10^{6} / \mathrm{ml}\right)\end{array}$ & $\begin{array}{l}\text { Motility } \\
(\%)\end{array}$ & $\begin{array}{l}\text { Atypical } \\
\text { form (\%) }\end{array}$ & & & & \\
\hline $\begin{array}{l}\text { Yurov et al., } \\
1996 \text { [11] }\end{array}$ & 1 & $40 \%$ & / & 1.0 & $1 \%$ & $97 \%$ & $100 \%$ & I & ICSI: 5 cycles & no pregnancies \\
\hline $\begin{array}{l}\text { In't veld et al., } \\
1997[8]\end{array}$ & 1 & $100 \%$ & $\begin{array}{l}1 \text { to } 3 \\
\text { flagella }\end{array}$ & 15.0 & & & $100 \%$ & $\begin{array}{l}\text { Head area } \\
25.4+/-4 \mu \mathrm{m}^{2}\end{array}$ & ICSI: 1 cycles & $\begin{array}{l}15 \text { oocytes, } 2 \text { embryos } \\
\text { transferred, no pregnancies }\end{array}$ \\
\hline $\begin{array}{l}\text { Weissenberg et al., } \\
1998 \text { [14] }\end{array}$ & 1 & $100 \%$ & & 10.3 & $23.7 \%$ & & $99.2 \%$ & / & ICSI: 2 cycles & $\begin{array}{l}14 \text { oocytes, } 2 \text { embryos } \\
\text { transferred, no pregnancies }\end{array}$ \\
\hline \multirow{3}{*}{$\begin{array}{l}\text { Kahraman et al., } \\
1999[6]\end{array}$} & \multirow[t]{3}{*}{17} & \multirow{3}{*}{\multicolumn{2}{|c|}{$68.5 \%$}} & \multirow[t]{3}{*}{3.8} & \multirow[t]{3}{*}{$4.7 \%$} & \multirow[t]{3}{*}{$0 \%$} & \multirow[t]{3}{*}{ not determined } & \multirow[t]{3}{*}{ / } & \multirow[t]{3}{*}{ ICSI: 22 cycles } & Fertilization rate: $43 \%$ \\
\hline & & & & & & & & & & 9 embryo transfers \\
\hline & & & & & & & & & & 2 pregnancies and 3 live births \\
\hline $\begin{array}{l}\text { Viville et al., } \\
2002 \text { [40] }\end{array}$ & 1 & $\begin{array}{l}64 \% \text { with } \\
\text { multiple flagell }\end{array}$ & & 2.0 & $<5 \%$ & & $89.2 \%$ & / & ICSI: 3 cycles & No pregnancies. \\
\hline $\begin{array}{l}\text { Benzaken et al., } \\
2001 \text { [3] }\end{array}$ & 1 & $100 \%$ & $72 \%$ & 2.0 & $<5 \%$ & & $100 \%$ & / & Not performed & / \\
\hline \multirow[t]{3}{*}{$\begin{array}{l}\text { Devillard et al., } \\
2002[17]\end{array}$} & \multirow[t]{3}{*}{3} & $\begin{array}{l}100 \% \\
\text { (irregular } \\
\text { shape) }\end{array}$ & $30 \%$ & 3.2 & $25 \%$ & & $100 \%$ & \multirow[t]{3}{*}{ / } & \multirow[t]{3}{*}{ Not performed } & \multirow[t]{3}{*}{ / } \\
\hline & & $>95 \%$ & / & 30.0 & reduced & & $100 \%$ & & & \\
\hline & & $100 \%$ & / & 10.0 & reduced & & $100 \%$ & & & \\
\hline \multirow{3}{*}{$\begin{array}{l}\text { Lewis-Hones et al., } \\
2003[15]\end{array}$} & \multirow{3}{*}{3} & $46 \%$ & $72 \%$ & \multirow{3}{*}{$\begin{array}{l}\text { Oligo- } \\
\text { asthenospermia }\end{array}$} & & $100 \%$ & $100 \%$ & \multirow[t]{3}{*}{ / } & \multirow[t]{3}{*}{ Not performed } & \multirow[t]{3}{*}{ / } \\
\hline & & $60 \%$ & $49 \%$ & & & & $46 \%$ & & & \\
\hline & & $54 \%$ & $50 \%$ & & & & $82.5 \%$ & & & \\
\hline \multirow{3}{*}{$\begin{array}{l}\text { Vicari et al., } \\
2003[18]\end{array}$} & \multirow[t]{3}{*}{3} & $54.3 \%$ & / & $14.4 \%$ & $14 \%$ & $100 \%$ & $69.5 \%$ & / & Not performed & / \\
\hline & & $18.9 \%$ & & $3.7 \%$ & $13 \%$ & & $5.2 \%$ & & & \\
\hline & & $26.5 \%$ & & $0.25 \%$ & $8 \%$ & & $13.1 \%$ & & & \\
\hline Kahraman et al., & 21 & predominantly & & 6.7 & $14.1 \%$ & / & / & / & ICSI and PGD, & Implantation rate: $25 \%$ \\
\hline $2004[31]$ & & $\begin{array}{l}\text { macrocepnallic } \\
\text { pinhead sperm }\end{array}$ & atozoa & & & & & & & Pregnancy rate: 33 \% \\
\hline & & & & & & & & & & Abortion rate: $14.3 \%$ \\
\hline & 52 & & & 11.9 & $17 \%$ & & & & ICSI (no PGD), & Implantation rate: $12.3 \%$ \\
\hline & & & & & & & & & & Pregnancy rate: $27.8 \%$ \\
\hline & & & & & & & & & & Abortion rate: $46.7 \%$ \\
\hline $\begin{array}{l}\text { Guthauser et al., } \\
2006[4]\end{array}$ & 2 & $\begin{array}{l}91 \% \text { with mul } \\
\text { flagella }\end{array}$ & & 30.4 & $0 \%$ & $100 \%$ & $\begin{array}{l}100 \%, 95 \% \text { for spermatozoa } \\
\text { normal-sized heads }\end{array}$ & with & Not performed & / \\
\hline & & $\begin{array}{l}82 \% \text { with mul } \\
\text { flagella }\end{array}$ & & 3.6 & & & $\begin{array}{l}100 \%, 90 \% \text { for spermatozoa } \\
\text { normal-sized heads }\end{array}$ & with & & \\
\hline
\end{tabular}


Table 1 Reports of patients with large-headed spermatozoa and the associated ART decisions and outcomes (Continued)

\begin{tabular}{|c|c|c|c|c|c|c|c|c|c|c|}
\hline \multirow{4}{*}{$\begin{array}{l}\text { Achard et al., } \\
2007[10]\end{array}$} & \multirow[t]{4}{*}{4} & $29.5 \%$ & / & 8.2 & $32 \%$ & $70 \%$ & $51.4 \%$ & \multirow[t]{4}{*}{ / } & \multirow[t]{4}{*}{ ICSI, 7 cycles } & \multirow[t]{2}{*}{ Fertilisation rate: $65.6 \%$} \\
\hline & & $22 \%$ & / & 6.2 & $33 \%$ & $69 \%$ & $43.6 \%$ & & & \\
\hline & & $49.7 \%$ & / & 1.3 & $7 \%$ & $91.5 \%$ & $71.7 \%$ & & & \multirow[t]{2}{*}{ One live birth (for patient 1) } \\
\hline & & $19 \%$ & / & 1.7 & $9 \%$ & $96 \%$ & $25.6 \%$ & & & \\
\hline $\begin{array}{l}\text { Perrin et al., } \\
2008 \text { [16] }\end{array}$ & 1 & $62 \%$ & $54 \%$ & 2.8 & $0 \%$ & $100 \%$ & $99.3 \%$ & / & Not performed & / \\
\hline $\begin{array}{l}\text { Guthauser et al., } \\
2011 \text { [7] }\end{array}$ & 1 & $47 \%$ & $0 \%$ & 28.3 & $8 \%$ & $98 \%$ & $3 \%$ & $\begin{array}{l}\text { Uncondensed } \\
\text { chromatin:46 \% }\end{array}$ & ICSI & Lost to follow-up \\
\hline \multirow{2}{*}{$\begin{array}{l}\text { Ben Khelifa et al., } \\
2011 \text { [9] }\end{array}$} & \multirow[t]{2}{*}{2} & $100 \%$ & $28 \%$ & 0.9 & $8 \%$ & MAl: 3.5 & \multirow[t]{2}{*}{ / } & \multirow[t]{2}{*}{ / } & ICSI, 6 cycles & Fertilization rate: $17.0 \%$ \\
\hline & & $100 \%$ & $52 \%$ & 0.8 & $7 \%$ & MAl: 3.6 & & & ICSI, 5 cycles & No pregnancies \\
\hline $\begin{array}{l}\text { Guthauser et al., } \\
2013 \text { [26] }\end{array}$ & 1 & $\begin{array}{l}12 \%, \\
\text { Normally } \\
\text { shaped }\end{array}$ & $0 \%$ & 89 & $40 \%$ & $80 \%$ & $\begin{array}{l}78 \%, 68 \% \text { for spermatozoa } \\
\text { with normal-sized heads }\end{array}$ & \multirow[t]{2}{*}{$\begin{array}{l}\text { Uncondensed } \\
\text { chromatin: } 11 \%\end{array}$} & Not performed & / \\
\hline $\begin{array}{l}\text { Shimizu et al., } \\
2012[5]\end{array}$ & 1 & $\begin{array}{l}\text { "Almost all" } \\
\text { (exact \% not } \\
\text { specified) }\end{array}$ & & 0.2 & $25 \%$ & $99.7 \%$ & Not determined & & ICSI & One ICSI cycle, one live birth \\
\hline
\end{tabular}

Studies with sample sizes evaluating the relationship between the percentage of spermatozoa with large heads, multiple flagella, semen characteristics, percentage of spermatozoa with aneuploidies, ART (assisted reproductive technology) performed, and outcomes 
Table 2 Suggested additional analyses performed for ART decision

Light microscopy

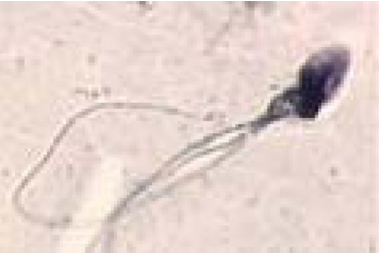

(Photo 1)
Sperm head measurement (200 cells, CASMA)

FISH analysis on raw semen (with $\mathrm{X} / \mathrm{Y} / 18$ probes) Photo 3

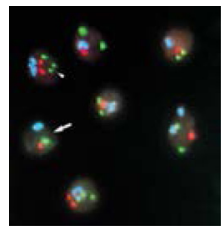

Determination of the percentage of spermatozoa with a large head and the percentage with

normal-sized head

$100 \%$ aneuploidy,

$<100 \%$ aneuploidy

Donor sperm or adoption

(1)

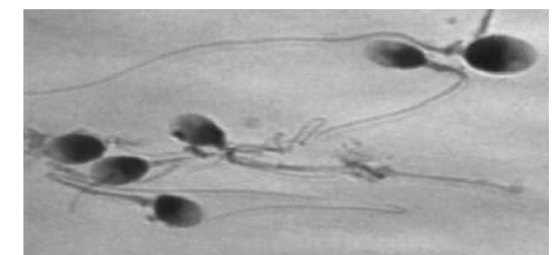

(Photo 2)

Determination of the percentage of spermatozoa with a large head

A normal percentage of spermatozoa with An elevated percentage of spermatozoa with abnormal chromosome content

abnormal chromosome content

Percentage of aneuploid spermatozoa Low

Percentage of aneuploid

spermatozoa Low sperm

sperm aneuploidy?

spermatozis of with a

normal-sized head Photo 4

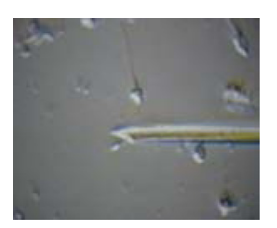

AURKC screening

Chromatin condensation rate in whole sperm

Chromatin condensation assay on spermatozoa with a normal-sized head (sperm measurement + aniline

blue staining

Genetic counselling

Decision on ART according to the results of an aneuploidy assessment, AURKC mutation screening and the couple's history of fertility/infertility
Optional

Within the normal range

Decision on ART according to the sperm chromatin condensation rate, the FISH result on whole sperm and (in some cases) the percentage of spermatozoa with a normal-sized head and the couple's history of fertility/infertility

Decision on ART according to sperm phenotype, light microscopy examination, FISH analysis, AURC screening, chromatine condensation 
nevertheless performed using spermatozoa with an "almost normal form" [5].

\section{The potential value of additional analyses of sperm with} large-headed spermatozoa (Table 2)

Additional assessments may prove useful for better characterizing sperm defects, assisting with the decisionmaking process (i.e. initiation of ART with the patient's sperm or with donor sperm) and choosing the best spermatozoon for injection if ICSI with the patient's sperm is undertaken.

\section{Sperm head morphometry with light microscopy}

In cases where all the spermatozoa have a large head, an irregular shape and multiple flagella (as initially described by Nistal et al. in 1977 [12]), MSHS is easy to diagnose. In contrast, distinguishing between normal-headed spermatozoa and normally shaped spermatozoa with enlarged head can be more difficult. In such a case, the precise measurement of the head's length and width (at least) with a micrometre eyepiece is recommended [1]. The sperm head's dimensions (i.e. length, width, surface area and perimeter) are useful for detecting slight variations in size. The use of computer-assisted sperm morphometry analysis (CASMA) can reduce intra- and inter-operator variability. In animal models, CASMA is commonly used to provide objective sperm head measurements [19-23]. Hingst et al.'s study of cat semen found that an abnormally large head size was associated with incompletely condensed chromatin [19]. Casey et al. reported that subfertile stallions had a higher sperm head surface area than fertile stallions [24]. Lastly, Dahlbom et al. found two populations of dog spermatozoa with different head sizes [20].

Similarly, CASMA has been used to evaluate the fertility of men with large-headed spermatozoa [7, 25, 26]. However, it is important to note that head dimension parameters depend on the staining methods used. When compared with the classic modified Papanicolaou procedure, rapid staining procedures (such as Hemacolor ${ }^{\circ}$ or DiffQuick methods) cause the spermatozoa to swell and thus alter the head's morphology. A recent review reported significant inter-method differences, with sperm head surface areas ranging from $9.45 \pm 1.35 \mu \mathrm{m}^{2}$ (for Papanicolaou staining) to $18.83 \pm 1.37 \mu \mathrm{m}^{2}$ (for Hemacolor ${ }^{\circ}$ staining) [27]. Given the heterogeneity and absence of standardization of procedures available for sperm head measurement after staining, one must be very cautious when establishing size thresholds. Innovative CASMA technologies based on fluorescence or phase contrast microscopy may facilitate standardization [27].

\section{Sperm chromatin condensation assays}

In a study of bull spermatozoa, Ferrari et al. showed that an abnormally high nuclear volume was associated with altered chromatin condensation [21]. Revay et al. also reported an alteration of chromatin condensation in large-headed bull spermatozoa [28]. Sperm chromatin condensation (using the aniline blue assay) might be useful in cases featuring large-headed but regularly shaped spermatozoa [7]. It has recently been shown that large-headed spermatozoa present a high degree of noncondensed chromatin [29]. Although the utility of sperm chromatin condensation assays is still subject to debate, these tests might provide a more accurate prognosis for patients with a high percentage of large-headed spermatozoa (Table 3).

\section{Intracytoplasmic injection of morphologically selected spermatozoa (IMSI)}

It has been suggested that IMSI can discriminate between normally shaped and abnormally shaped spermatozoa prior to microinjection. Our group showed that IMSI enabled the selection of haploid spermatozoa in semen sample from patients with MSHS and homozygous AURKC mutation (c.144delC). Unfortunately, a FISH analysis showed that none of the six selected spermatozoa was euploid [30]. Although motile sperm organelle morphology examinations (such as the IMSI-strict procedure) have not yet been tested in men with largeheaded spermatozoa, we suggest that it might be able to exclude abnormal sperm in samples of semen with a low-to-moderate proportion of large-headed spermatozoa (Table 3).

\section{Preimplantation genetic diagnosis (PGD)}

Kahraman et al. reported pregnancy rates of $33.3 \%$ after 23 PGD cycles and $27.8 \%$ after 60 non-PGD cycles. The implantation rate was higher in the PGD group (25.0\%) than in the non-PGD group (12.3\%). Forty six percent of the biopsied embryos were abnormal. One spontaneous abortion occurred in the PGD group (14.3\%), whereas seven of the 15 pregnancies obtained in the non-PGD group resulted in spontaneous abortion (46.7\%) [31].

\section{Flow cytometry}

Flow cytometry is able to discriminate between spermatozoa that differ in size and granularity. Volume-based sorting was initially used to separate X-and Y-bearing bull spermatozoa, since slight differences in sperm DNA content are reflected in the sperm head volume [32]. Significant enrichment of Y-/X-sorted spermatozoa was achieved by coupling interferometry with flow cytometry in the absence of fluorescent staining [33]. Although the enrichment was not great enough to obtain sex-preselected offspring with a high degree of confidence, the technique might possibly be effective in men with large-headed spermatozoa. Indeed, some researchers have reported that the presence of large-headed spermatozoa is associated 
Table 3 Proposed classification for semen containing large-headed spermatozoa and ART possibilities decision

\begin{tabular}{|c|c|c|c|c|c|}
\hline $\begin{array}{l}\text { Light microscopy for } \\
\text { large-headed spermatozoa }\end{array}$ & $\begin{array}{l}\text { Proposal of percentage } \\
\text { of spermatozoa with } \\
\text { large heads }\end{array}$ & $\begin{array}{l}\text { Proposal of FISH on selected } \\
\text { spermatozoa with a normal } \\
\text { head size }\end{array}$ & Additional analysis proposal & Classification & $\begin{array}{l}\text { ART possibility } \\
\text { decision }\end{array}$ \\
\hline \multirow[t]{3}{*}{$\begin{array}{l}\text { Irregular head shape and } \\
\text { multiple flagella }\end{array}$} & $100 \%$ & Not recommend & Screen for AURK mutations & Type I & $\begin{array}{l}\text { Intracouple ART } \\
\text { contraindicated }\end{array}$ \\
\hline & $<100 \%$ & No euploid spermatozoa & Screen for AURK mutations & Type ॥A & $\begin{array}{l}\text { Intracouple ART } \\
\text { contraindicated }\end{array}$ \\
\hline & & $\begin{array}{l}\text { Presence of euploid } \\
\text { spermatozoa }\end{array}$ & Screen for AURK mutations? & Type IIB & $\begin{array}{l}\text { ICSI + PGD if } \\
\text { available }\end{array}$ \\
\hline \multirow[t]{3}{*}{$\begin{array}{l}\text { Normal head shape and a } \\
\text { single flagella }\end{array}$} & $>10 \%^{a}$ & $\begin{array}{l}\text { Normal level of aneuploid } \\
\text { spermatozoa }\end{array}$ & $\begin{array}{l}\text { Normal sperm chromatin } \\
\text { condensation for spermatozoa } \\
\text { with normal size head }\end{array}$ & Type IIIA & $\begin{array}{l}\text { ICSI with } \\
\text { spermatozoa } \\
\text { with normal size } \\
\text { head }\end{array}$ \\
\hline & & $\begin{array}{l}\text { Normal level of aneuploid } \\
\text { spermatozoa }\end{array}$ & $\begin{array}{l}\text { Normal sperm chromatin } \\
\text { condensation }\end{array}$ & Type IIIB & Intracouple ART \\
\hline & & $\begin{array}{l}\text { High level of aneuploid } \\
\text { spermatozoa }\end{array}$ & $\mathrm{FISH}$ & Type IIIC & $\begin{array}{l}\text { ICSI + PGD if } \\
\text { available }\end{array}$ \\
\hline
\end{tabular}

Classification of sperm with enlarged head according to light microscopy evaluation, percentage of spermatozoa with large heads, FISH studies, additional analysis performed, and ART (assisted reproductive technology). a'Guthauser et al., 2013 [26]

with a 3-fold relative increase in nuclear volume [13], which might be more easily detected and gated out using conventional flow cytometry (with or without interferometry).

To the best of our knowledge, stain-free flow cytometry techniques have not been used to sort viable spermatozoa in cases of patients with large-headed spermatozoa. However, flow cytometry with fluorescent DNA staining has already been used to isolate specific bovine and human sperm populations prior to FISH analysis [14, 34]. The combination of flow cytometry sorting with FISH may (i) reveal the presence of haploid spermatozoa with a normal head size that can be used for ICSI and (ii) provide an accurate prognosis in cases in which the spermatozoon head size is not uniform.

\section{Fish analysis}

FISH analysis of raw semen (usually with three chromosome probes; see the photo in Table 2) is highly recommended when seeking to assess the feasibility of intracouple ICSI. In 1996, Yurov et al. analysed the semen of an infertile man in whom $40 \%$ of the spermatozoa had abnormally large heads. The majority of spermatozoa with normal-sized heads were haploid and free from chromosomal aneuploidies, whereas most spermatozoa with large heads were diploid [11]. However, no pregnancies resulted from five ICSI cycles. In't Veld et al. reported on a patient in whom all the spermatozoa had large heads and abnormal chromosome content [8]. A previous ICSI cycle had yielded a low fertilization rate (4 oocytes out of 15), two transfers and no pregnancies. The researchers suggested that a FISH analysis should always be used to evaluate the genetic risks. FISH analyses can also be performed on spermatozoa that would be selected and used for ICSI (i.e. spermatozoa with a normal-sized head, when available; see the photo in Table 2) $[4,7,26]$.

\section{AURKC sequence analysis}

This genetic analysis should be applied to patients with MSHS, whose spermatozoa have large heads, irregular shapes, multiple flagella and an abnormal chromosome content. In 2007, Dieterich et al. discovered that a high proportion of men with MSHS carried a homozygous mutation (c.144delC) in the Aurora kinase C (AURKC) gene [35]. In 2009, Dietrich et al. demonstrated that large-headed spermatozoa from $A U R K C$-deficient patients were tetraploid - indicating that meiosis cannot be completed in the absence of functional AURKC [36]. These findings suggest that all spermatozoa from patients bearing AURKC mutations will have chromosome abnormalities and that ICSI should not be attempted. A comprehensive review of AURKC mutations and sperm DNA content in humans was published recently [37]. Lastly, AURKC sequence analysis should be performed in some ethnic groups; it has been demonstrated that the c.144delC homozygous AURKC mutation is the leading genetic cause of infertility in North African men [38], although the prevalence of heterozygosity seems to be five times lower in Tunisian males $(0.4 \%)$ than in men from North Africa as a whole (2\%) or in men from Morocco (1.7\%) [39].

\section{Karyotype}

No specific abnormalities have been found in published cases of MSHS or large-headed spermatozoa. Although karyotyping and molecular testing for AZF microdeletions should be used for patients presenting with severe non-obstructive oligozoospermia, we consider that these analyses are not of value in this particular situation. 
Our classification proposition of enlarged sperm (Table 3) We propose here a classification for semen containing large-headed spermatozoa: types I, IIA, IIB, IIIA, IIIB, IIIC and ART possibilities are summarized in the last column according to data of literature review developed in this article.

\section{Conclusion}

Since the first case report of MSHS by Nistal et al. in 1977 [12], only 5 babies have been born to patients with large-headed spermatozoa enrolled in ART programmes. After additional analyses have been performed (as suggested in Table 2), genetic counselling may establish the likelihood of pregnancy with the patient's spermatozoa (with or without PGD). The objectives of counselling are to (i) avoid unnecessary ICSI cycles when intracouple ART is contraindicated and (ii) estimate the usefulness of PGD/FISH when ICSI is possible. At last we propose a 6 types classification (I, IIA, IIB, IIIA, IIB, IIIC) based on sperm defects, associated with a ART possibility decision.

\section{Abbreviations}

ART, assisted reproductive technology; AURKC, aurora kinase C; CASMA, computer-assisted sperm morphometry analysis; DNA, desoxyribonucleic acid: FISH, flourescence in situ hybrizydation; ICSI, intracytoplasmic sperm injection; IMSI, intracytoplasmic morphologically selected sperm injection; MSHS, macrocephalic sperm head syndrome; PGD, preimplanttion genetic diagnosis

\section{Funding}

None

Availability of data and materials

Not applicable

\section{Authors' contributions}

BG collected data and wrote the manuscript with XPV. FB and FV revised the manuscript for critical content. All authors have approved the final manuscript.

\section{Competing interest}

The authors declare that they have no competing interests.

\section{Author details \\ ${ }^{1}$ Laboratoire de Biologie de la Reproduction, Hôpital Tenon, Paris, France. ${ }^{2}$ Centre d'AMP Nataliance, Laboratoire Medibio, Saran, France. ${ }^{3} \mathrm{GIG}$, EA7404, Université Versailles St Quentin en Yvelines, Montigny le Bretonneux, France. ${ }^{4}$ Unité de Biologie de la Reproduction, $\mathrm{CH}$ de Poissy St Germain, Poissy, France.}

Received: 4 January 2016 Accepted: 9 June 2016

Published online: 08 July 2016

\section{References}

1. World Health Organization. WHO laboratory manual for the examination and processing of human semen. 5th ed. Geneva: World Health Organization; 2010

2. Viville S, Mollard R, Bach ML, Falquet C, Gerlinger P, Warter S. Do morphological anomalies reflect chromosomal aneuploidies?: case report. Hum Reprod. 2000;15:2563-6.

3. Benzacken B, Gavelle FM, Martin-Pont B, Dupuy O, Lievre N, Hugues JN, et al. Familial sperm polyploidy induced by genetic spermatogenesis failure: case report. Hum Reprod. 2001;16:2646-51.
4. Guthauser B, Vialard F, Dakouane M, Izard V, Albert M, Selva J. Chromosomal analysis of spermatozoa with normal-sized heads in two infertile patients with macrocephalic sperm head syndrome. Fertil Steril. 2006;85:750.e755-7.

5. Shimizu Y, Kiumura F, Kaku S, Izuno M, Tomita K, Thumkeo D, et al. Successful delivery following ICSI with macrocephalic sperm head syndrome: a case report. Reprod Biomed Online. 2012;24:603-5.

6. Kahraman S, Akarsu C, Cengiz G, Dirican K, Sozen E, Can B, et al. Fertility of ejaculated and testicular megalohead spermatozoa with intracytoplasmic sperm injection. Hum Reprod. 1999;14:726-30.

7. Guthauser B, Albert M, Ferfouri F, Ray PF, Rabiey G, Selva J, et al. Inverse correlation between chromatin condensation and sperm head size in a case of enlarged sperm heads. Reprod Biomed Online. 2011;23:711-6.

8. In't Veld PA, Broekmans FJ, de France HF, Pearson PL, Pieters MH, van Kooij RJ. Intracytoplasmic sperm injection (ICSI) and chromosomally abnormal spermatozoa. Hum Reprod. 1997:12:752-4.

9. Ben Khelifa M, Zouari R, Harbuz R, Halouani L, Arnoult C, Lunardi J, et al. A new AURKC mutation causing macrozoospermia: implications for human spermatogenesis and clinical diagnosis. Mol Hum Reprod. 2011;17:762-8.

10. Achard V, Paulmyer-Lacroix O, Mercier G, Porcu G, Saias-Magnan J, Metzler-Guillemain C, et al. Reproductive failure in patients with various percentages of macronuclear spermatozoa: high level of aneuploid and polyploid spermatozoa. J Androl. 2007;28:600-6.

11. Yurov YB, Saias MJ, Vorsanova SG, Erny R, Soloviev IV, Sharonin VO, et al. Rapid chromosomal analysis of germ-line cells by FISH: an investigation of an infertile male with large-headed spermatozoa. Mol Hum Reprod. 1996;2:665-8.

12. Nistal M, Paniagua R, Herruzo A. Multi-tailed spermatozoa in a case with asthenospermia and teratospermia. Virchows Arch B Cell Pathol. 1977;26:111-8.

13. Escalier D. Human spermatozoa with large heads and multiple flagella: quantitative ultrastructural study of 6 cases. Biol Cell. 1983;48:65-74.

14. Weissenberg R, Aviram A, Golan R, Lewin LM, Levron J, Madgar I, et al. Concurrent use of flow cytometry and fluorescence in-situ hybridization techniques for detecting faulty meiosis in a human sperm sample. Mol Hum Reprod. 1998:4:61-6.

15. Lewis-Jones I, Aziz N, Seshadri S, Douglas A, Howard P. Sperm chromosomal abnormalities are linked to sperm morphologic deformities. Fertil Steril. 2003:79:212-5.

16. Perrin A, Morel F, Moy L, Colleu D, Amice V, De Braekeleer M. Study of aneuploidy in large-headed, multiple-tailed spermatozoa: case report and review of the literature. Fertil Steril. 2008;90:1201.e1213-1207.

17. Devillard F, Metzler-Guillemain C, Pelletier R, DeRobertis C, Bergues U, Hennebicq S, et al. Polyploidy in large-headed sperm: FISH study of three cases. Hum Reprod. 2002;17:1292-8.

18. Vicari E, de Palma A, Burrello N, Longo G, Grazioso C, Barone N, et al. Absolute polymorphic teratozoospermia in patients with oligo-asthenozoospermia is associated with an elevated sperm aneuploidy rate. J Androl. 2003;24:598-603.

19. Hingst O, Blottner S, Franz C. Chromatin condensation in cat spermatozoa during epididymal transit as studied by aniline blue and acridine orange staining. Andrologia. 1995;27:275-9.

20. Dahlbom M, Andersson M, Vierula M, Alanko M. Morphometry of normal and teratozoospermic canine sperm heads using an image analyzer: work in progress. Theriogenology. 1997:48:687-98.

21. Ferrari MR, Spirito SE, Giuliano SM, Fernandez HA. Chromatin cytophotometric analysis of abnormal bovine spermatozoa. Andrologia. 1998:30:85-9.

22. Saravia F, Nunez-Martinez I, Moran JM, Soler C, Muriel A, Rodriguez-Martinez H, et al. Differences in boar sperm head shape and dimensions recorded by computer-assisted sperm morphometry are not related to chromatin integrity. Theriogenology. 2007:68:196-203.

23. Marti Jl, Aparicio IM, Garcia-Herreros M. Sperm morphometric subpopulations are differentially distributed in rams with different maturity age in cryopreserved ejaculates. Theriogenology. 2011;76:97-109.

24. Casey PJ, Gravance CG, Davis RO, Chabot DD, Liu IK. Morphometric differences in sperm head dimensions of fertile and subfertile stallions. Theriogenology. 1997;47:575-82.

25. Guichaoua MR, Mercier G, Geoffroy-Siraudin C, Paulmyer-Lacroix O, Lanteaume A, Metzler-Guillemin C, et al. Macrocephalic spermatozoa. What would be the impact on reproduction? Gynecol Obstet Fertil. 2009:37:703-11.

26. Guthauser B, Boitrelle F, Albert M, Ketata F, Meynant C, Ferfouri F, et al. Contraindication of ART following a sperm FISH analysis, even though only $12 \%$ of the spermatozoa had enlarged heads. Syst Biol Reprod Med. 2013;59:214-7.

27. Yaniz JL, Soler C, Santolaria P. Computer assisted sperm morphometry in mammals: a review. Anim Reprod Sci. 2015;156:1-12. 
28. Revay T, Nagy S, Kopp C, Flyckt A, Rens W, Rath D, et al. Macrocephaly in bull spermatozoa is associated with nuclear vacuoles, diploidy and alteration of chromatin condensation. Cytogenet Genome Res. 2009;126:202-9.

29. Boitrelle F, Pagnier M, Athiel Y, Swierkowski-Blanchard N, Torre A, Alter L, et al. A human morphologically normal spermatozoon may have noncondensed chromatin. Andrologia. 2015;47:879-86.

30. Chelli MH, Albert M, Ray PF, Guthauser B, Izard V, Hammoud I, et al. Can intracytoplasmic morphologically selected sperm injection be used to select normal-sized sperm heads in infertile patients with macrocephalic sperm head syndrome? Fertil Steril. 2010;93:1347-e1341-1345.

31. Kahraman S, Sertyel S, Findikli N, Kumtepe Y, Oncu N, Melil S, et al. Effect of PGD on implantation and ongoing pregnancy rates in cases with predominantly macrocephalic spermatozoa. Reprod Biomed Online. 2004;9:79-85.

32. van Munster EB, Stap J, Hoebe RA, te Meerman GJ, Aten JA. Difference in volume of $X$ - and $Y$-chromosome-bearing bovine sperm heads matches difference in DNA content. Cytometry. 1999;35:125-8.

33. van Munster EB. Interferometry in flow to sort unstained $X$ - and Y-chromosome-bearing bull spermatozoa. Cytometry. 2002;47:192-9.

34. Revay T, Kopp C, Flyckt A, Taponen J, ljas R, Nagy S, et al. Diploid spermatozoa caused by failure of the second meiotic division in a bull. Theriogenology. 2010;73:421-8.

35. Dieterich K, Soto Rifo R, Faure AK, Hennebica S, Ben Amar B, Zahi M, et al. Homozygous mutation of AURKC yields large-headed polyploid spermatozoa and causes male infertility. Nat Genet. 2007;39:661-5.

36. Dieterich K, Zouari R, Harbuz R, Vialard F, Martinez D, Bellayou H, et al. The Aurora Kinase C c.144delC mutation causes meiosis I arrest in men and is frequent in the North African population. Hum Mol Genet. 2009;18:1301-9.

37. Coutton C, Escoffier J, Martinez G, Arnoult C, Ray PF. Teratozoospermia: spotlight on the main genetic actors in the human. Hum Reprod Update. 2015;21:455-85.

38. Ounis L, Zoghmar A, Coutton C, Rouabah L, Hachemi M, Martinez D, et al. Mutations of the aurora kinase $C$ gene causing macrozoospermia are the most frequent genetic cause of male infertility in Algerian men. Asian J Androl. 2015;17:68-73.

39. Ghedir H, Gribaa M, Mamai O, Ben Charfeddine I, Braham A, Amara A, et al. Macrozoospermia: screening for the homozygous c.144delC mutation in AURKC gene in infertile men and estimation of its heterozygosity frequency in the Tunisian population. J Assist Reprod Genet. 2015;32:1651-8.

40. MacLean 2nd JA, Hu Z, Welborn JP, Song HW, Rao MK, Wayne CM, et al. The RHOX homeodomain proteins regulate the expression of insulin and other metabolic regulators in the testis. J Biol Chem. 2013;288:34809-25.

\section{Submit your next manuscript to BioMed Central and we will help you at every step:}

- We accept pre-submission inquiries

- Our selector tool helps you to find the most relevant journal

- We provide round the clock customer support

- Convenient online submission

- Thorough peer review

- Inclusion in PubMed and all major indexing services

- Maximum visibility for your research

Submit your manuscript at www.biomedcentral.com/submit

) Biomed Central 